Pak. j. sci. ind. res. Ser. A: phys. sci. 2019 62A(1) 20-27

\title{
Removal of Impurities from Indigenous (Chamlang) Coal by Using Froth Flotation Technology
}

\author{
Saadat Ullah Khan Suriab* and Rafi Ullah Khan ${ }^{\mathrm{a}}$ \\ ${ }^{a}$ ICET, University of the Punjab, New Quaid-e-Azam Campus, Lahore, Pakistan \\ ${ }^{b}$ Department of Chemical Engineering, BUITEMS, Takatu Campus, Baleli Road, Quetta, Pakistan
}

(received October 10, 2017; revised February 27, 2018; accepted March 13, 2018)

\begin{abstract}
Indigenous (Chamlang) coal possesses excessive concentrations of impurities, such as ash and organic and inorganic sulphur. In the present research froth flotation technique was applied for reducing inorganic sulphur and ash content in coal. Frothing agent, $\mathrm{pH}$, separation time and air velocity were the main parameters employed to reduce ash content in the indigenous coal. The optimum values of flotation parameters by including $\mathrm{pH}$, air velocity and separation time were found to be 7, $90 \mathrm{scf} / \mathrm{h}$ and $55 \mathrm{~min}$. Keeping parameters at their optimum values, better quality of coal was obtained by reducing ash and sulphur content to 57 and $50.757 \%$ respectivety.
\end{abstract}

Keywords: sulphur removal, froth flotation, $\mathrm{pH}$, separation time, indigenous coal

\section{Introduction}

Today one of the most concerning issues is the energy crisis which is a main cause to the earth's fast reduction in the fossil fuel resource. To overcome this problem, many countries are now utilizing their coal reserves for fuels production. Coal is considered as a vital energy resource for generating electricity as well as for obtaining useful hydrocarbons products such as gasoline, diesel, naphtha and other vacuum products till the recent past. Coal is also a replacement for oil, natural gas, fertilizer and bio-mass. Oil, natural gas, fertilizer and bio-mass sectors are producing highly toxic pollutants such as volatile organic compound (VOC), NOx's and SOx's. Coal possesses high calorific value and it is utilized to produce heat energy in different power or industrial sectors. In many countries where sizeable energy resources of natural gas or fuel oil are not present; coal is endeavoring to transfer their power zone to other feasible energy sector.

Coal normally possesses a high content of disparate metallic and non-metallic impurities, seed process and environmental troubles in its consumption cycle. Attributable to these considerations, numerous research works have been conducted for elimination of these impurities (ash, sulphur, sulphates, iron, and silicates). Sulphur is one of the prime environmental pollutant that generate sulphur oxides and hydrogen sulphides on burning. Acid rains and green-house gases possess harmful effects on agricultural zones.

*Author for correspondence; E-mail: saadatsuri@hotmail.com
Sulphur oxides cause disruption in natural ozone layer thickness. Damage to metal structures due to erosion and gasping troubles to humans and animals are disagreeable effects of sulphur and its amalgam.

Elemental sulphur trace concentrations in coal are present in inorganic and organic configuration which limits its industrial applications. The higher sulphur content in the coal can be removed by incorporating physical, chemical and biotechnological methods. The most common practiced technologies for impurities removal from coal are discussed below (UCS, 2012; ALA, 2011).

Attia (1990) did the research work on desulphurization of coal by bio-conditioning prior to the froth flotation process. Thio Ferro-oxidans cells are used for bacterial transformation on the movement of micro-organism of coal samples. This is because coal is hydrophobic in nature and it is practicable to collect more froth through the froth. The ash forming materials are left behind as hydrophilic ones. This process is not performed to eliminate pyrite which carries an average hydrophobicity. The successful results have been achieved by reducing 50\% inorganic sulphur (Attia, 1990).

Attia et al. (1993) attained enhanced separation of pyrite from oxidized coal by froth flotation process. This research work is followed by bio-surface modification. The pyrite surfaces in the coal are made hydrophilic by Thio Ferro-oxidans cell. After bio-conditioning and bacterial removal, the coal slurry is fed to the froth 
flotation cell at $\mathrm{pH}$ 8. Improved pyritic sulphur removal efficiency was observed by Attia et al. (1993).

Ceylan and Zeki (2004) studied desulphurization of coal by the 'Froth Flotation' process. In this research, the solutions of zinc chloride $\left(\mathrm{ZnCl}_{2}\right)$ were used as the dense mediums, the methyl isobutyl frothing agents and kerosene oil was used as the collector. The effectiveness of this process depends on both the coal characteristic and the type of frothing agent. An effective pyritic sulphur removal (over_90\%) was achieved by the dense medium separation.

Boylu and Laskowski (2007) described the flotation systems in which emulsified oily collector were used as the process parameters. Solids recovery was contingent on the collector dosage rate and it implements the water recovery. The tests were carried out at low (1000 g/ton) and high (8000 g/ton) oil dosages. The effects of frothing agent inclusions on water transfer rates to the froth were observed. The experimental results suggested that the water transfer rate varied linearly in relation to the froth concentrate.

Maoming and Daniel (2010) research study demonstrated the nano-bubbles effects prior to the froth flotation process. The main parameters effect investigated during the study are the flow rate ratio between the nanobubble generators, the conventional size bubble generator, the superficial air velocity, collector dosage, frothing agent concentration, flotation feed rate, feed solids concentration and feed particle size. The main results demonstrated that the use of nano-bubbles in the flotation column increases the flotation recovery by $8 \%$ to $27 \%$ at a given product grade. The nano-bubbles increase the flotation rate constants of coal particles by $98.4 \%$. The selectivity index of the process increases up to $34 \%$, depending on the flotation feed characteristics and the flotation conditions.

$\mathrm{Xu}$ et al. (2014) worked on bioleaching wastes from fly ash by removing metals and salts. The incineration fly ash effect with Aspergillus niger on separation of metals salts was investigated. The biotechnological methods effectiveness for separation of metal and salts from X-ray spectroscopy and diffraction was observed.

Eriti (2017) worked on clean-up of fly ash content with Fusarium oxysporum and Pencillin galbrum from bioremediation. The Fusarium oxysporum and Pencillin galbrum fungi were found to be effective agents for clean-up fly ash. The bioremediation time is showing the significance of this research work towards its industrial application for scale up.

Firstly, in the physical methods, the coal particles are crushed into fine sizes and their surface area increases as the mass of each particle reduced. This steers to the evolution of surface force-control process or densitybased processes which are entirely irrelevant from the specific gravity- control process found in coal cleaning. In general, these advanced processes are disposed of yielding an immaculate coal product having low ash and low sulphur content (Jameson, 1992).

The sulphur concentrations in every configuration can be reduced by using different technologies. The elemental sulphur in inorganic configuration of coal is normally set up as sulphate and sulphides amalgam, which can be reduced by employing 'Froth Flotation' technology. This technology is found to be environmental friendly and economical for the separation of pyrite sulphur from coal. In 'Froth Flotation' process, the difference in surface wettability produced by the surfactant on selective coal surface can be taken as a base for the separation of physical sulphur. Surface properties of coal can be varied by using suitable wetting agent. There is also practiced frothing agent who is helpful by controlling the size and stability of air bubbles from which refined coal can be skimmed through the flotation column. The most commercially used frothing agents are oils (Osborne, 2012; MMSCL, 2010). In 'Froth Flotation' technology, air bubbles discern to come in contact with the coal surfaces in the coal-water slurry system. The desulphurized coal particles are affixed to the air bubbles and then they come to float on the surface, which are removed concurrently. Those particles which do not affix to the air bubbles remain in the liquid phase containing impurities (Manlapig et al., 2001; Callow, 1916).

The goal of the present research work is to elaborate the paramount up-gradation in the 'Froth Flotation' process effectiveness by reducing hazardous elements from coal. The highly improved results are being met by combining the novels parameters which are $\mathrm{pH}$, separation time and air velocity.

\section{Materials and Methods}

Materials. The flotation system consists of three phases of matter namely solid phase (refined solids particles 
to be separated), liquids phase (liquid solution) and gas phase (air to separate the solid particles from liquid solution).

The 'Froth Flotation' cell is 1 meter high and contains 8 inch of diameter cylinder. There is a sparger fitted at the bottom of cylindrical column for bubbling of air by using an air compressor. Rota meter is installed to measure air flow rate. The coal samples were taken from chamlang coal mines located in Quetta, Pakistan. The shredding of coal was done to the particle size of 250 micrometer and then dried at room temperature. The $\mathrm{KOH}$ and $\mathrm{HCl}$ are used as $\mathrm{pH}$ regulators. Conditioning of coal samples were carried out in a flotation column with stirrer by regulating the parameters of $\mathrm{pH}$, air velocity and separation time. Pine oil was used as frothing agent at the dosage rate of $1000 \mathrm{~g} / \mathrm{ton}$ to coal sample (Abdollahya and Moghaddam, 2006; Mitchell and Leomard, 1991).

$\mathrm{BaCl}_{2}, \mathrm{Na}_{2} \mathrm{CO}_{3}, \mathrm{Mg}(\mathrm{OH})_{2}, \mathrm{HCl}, \mathrm{C}_{14} \mathrm{H}_{14} \mathrm{~N}_{3} \mathrm{NaO}_{3} \mathrm{~S}, \mathrm{NH}_{3}$, $\mathrm{Br}, \mathrm{C}_{2} \mathrm{H}_{5} \mathrm{OH}$ and $\mathrm{HNO}_{3}$ are utilized to determine different types of sulphur in coal samples by following ASTM methods.

Equipments. 'Froth Flotation' cell, air compressor, rota meter, electric furnace, electric oven, $\mathrm{pH}$ meter, weight balance, sieves, filter- paper, conical splitter, jaw crusher, ball mill and pebble mill were used in this study.

Determination of moisture content. The total moisture content in the coal sample was measured by using ASTM D-3173 standard method. The moisture content in the coal sample was found to be $0.91 \%$.

Determination of volatile matter. The total content of volatile material in the coal was determined to be $16.20 \%$ by using ASTM D-3175 standard method (James, 2005a).

Determination of ash content. The content of ash in coal was determined to be $33.57 \%$ by using ASTM D3174 standard method (James, 2005b).

Determination of total sulphur content. The ASTM D-3177 standard method has been used to determine the total sulphur content in the coal sample. The total sulphur content was determined to be as $7.42 \%$ (James, 2005c).

$\mathrm{T}_{\mathrm{ST}}=\frac{\left(\left(\mathrm{A}-\mathrm{T}_{\mathrm{C}}\right)-\left(\mathrm{B}-\mathrm{T}_{\mathrm{B}}\right)\right) 13.73}{\mathrm{C}}=7.42 \%$

Determination of sulphate sulphur content. The sulphate sulphur content in the coal sample has been determined by following ASTM D-2492 standard method (James, 2005d).

$\mathrm{T}_{\mathrm{SS}}=\frac{\left(\left(\mathrm{E}-\mathrm{T}_{\mathrm{C}}\right)-\left(\mathrm{G}-\mathrm{T}_{\mathrm{B}}\right)\right) 13.73}{\mathrm{H}}=0.302 \%$

The sulphur content in the coal samples was calculated by using gravimetric analysis.

where:

$\mathrm{TsT}_{\mathrm{ST}}=$ Percentage of total sulphur content

$\mathrm{A}=$ Weight of crucible and $\mathrm{BaSO}_{4}$ after combustion

(g)

$\mathrm{B}=$ Weight of crucible and blank sample sulphate

$\mathrm{C}=$ Weight of original coal sample

$\mathrm{T}_{\mathrm{SS}}=$ The sulphate sulphur content in percentage

$\mathrm{E}=$ Weight of dish and barium sulphate after combustion in $(\mathrm{g})$

$\mathrm{T}_{\mathrm{C}}=$ Weight of dish and the sulphate utilized for combustion $(\mathrm{g})$

$T_{B}=$ Weight of dish utilized for combustion of the sample (g)

$\mathrm{G}=$ Weight of dish and the sulphate sample $(\mathrm{g})$

$\mathrm{H}=$ Weight of the actual coal sample for this analysis (g)

Determination of pyritic sulphur content. ASTM D2492 standards method has been used to determine the total content of pyritic sulphur in the coal. The precipitates resulted by determining the total content of sulphate sulphur in the coal samples were utilized for this analysis. The total iron content in the sample was determined by using atomic absorption and then total pyritic sulphur contents were determined.

$\mathrm{T}_{\mathrm{P}}=\frac{((\mathrm{RMENP})(\mathrm{S}-\mathrm{U}))}{\mathrm{L}}=4.15 \%$

where:

$\mathrm{T}_{\mathrm{P}}=$ The total pyritic sulphur content in percentage

$\mathrm{R}=$ The ratio of sulphur content to iron content

$\mathrm{M}=$ Dimensionless dilution element demanded for atomic absorption

$\mathrm{E}=$ The solution volume utilized in atomic absorption F100 (mL)

$\mathrm{N}=$ The conversion element required transfigure micrograms into gram

$\mathrm{P}=$ Conversion element required for transfigure numbers in percentage 
$\mathrm{S}=$ The total iron content in the sample $(\mathrm{mg} / \mathrm{mL})$

$\mathrm{U}=$ The Iron content in the blank sample $(\mathrm{mg} / \mathrm{mL})$

$\mathrm{L}=$ The actual coal sample weight utilized for this analysis (g)

Determination of organic sulphur content. The total organic sulphur content was determined by subtracting the total pyritic sulphur content and sulphate sulphur content from the total sulphur content.

$\mathrm{T}_{\mathrm{o}}=\left(\mathrm{T}_{\mathrm{ST}}-\left(\mathrm{T}_{\mathrm{SS}}+\mathrm{T}_{\mathrm{P}}\right)\right)=2.968 \%$

\section{Results and Discussion}

As previously stated, the coal samples were taken from Chamlang coal mine located in Quetta, Pakistan. The coal samples were delivered to the laboratory and dried out at room temperature. They were crushed by using jaw crusher and were grinded from ball mill and pebble mill to obtaine desired particle size. Coal samples were then subjected to the proximate and ultimate analysis and the results are indicated in Table 1-2.

Effect of $\mathbf{p H}$ on separation efficiency. These experimental tests were performed to see the effect of $\mathrm{pH}$ on the separation efficiency of sulphur/coal mixture. The potassium hydroxide $(\mathrm{KOH})$ and hydrochloric acid $(\mathrm{HCl})$ were taken as $\mathrm{pH}$ regulating parameters. The parameter separation time $=40 \mathrm{~min}$ and air velocity $=13 \mathrm{scf} / \mathrm{h}$ were kept constant during the experimental

Table 1. The proximate analysis of Chamlang coal

\begin{tabular}{ll}
\hline \hline Coal composition & wt.(\%) \\
\hline Ash & 33.57 \\
Volatile matter & 16.20 \\
Moisture & 0.91 \\
Fixed carbon & 49.32 \\
Total & 100.00 \\
\hline \hline
\end{tabular}

Table 2. The ultimate composition of Chamlang coal

\begin{tabular}{ll}
\hline \hline Coal composition & Wt. (\%) \\
\hline Carbon & 49.23 \\
Nitrogen & 1.00 \\
Hydrogen & 4.169 \\
Sulphur in organic form & 2.968 \\
Sulphur in pyrite form & 4.15 \\
Sulphur in Sulphate form & 0.302 \\
Total sulphur & 7.48 \\
Oxygen & 3.00 \\
Ash & 21.32 \\
Total & 100.00 \\
\hline \hline
\end{tabular}

tests. The stirrer was rotated at constant speed of 35 rpm for all the experimental tests. The experimental tests data is depicted in Table 3 and effects of $\mathrm{pH}$ on removal of impurities, sulphur and ash removals are shown in Fig. 1-2.

The coal samples were taken to observe the effect of $\mathrm{pH}$ on separation efficiency of (sulphur/coal) mixture and Table 3 shows that at $\mathrm{pH}=1$, in acidic media, although some purity in the coal sample was achieved but it possesses low value. The separation of sulphur and ash content demonstrate that the hydrophobicity of

Table 3. Effect of $\mathrm{pH}$ on removal of sulphur and ash.

\begin{tabular}{llllll}
\hline \hline $\begin{array}{l}\text { Test } \\
\text { no. }\end{array}$ & pH & $\begin{array}{l}\text { Sulphur } \\
\text { wt. }\end{array}$ & $\begin{array}{l}\text { Ash } \\
\text { wt. }\end{array}$ & $\begin{array}{l}\text { Sulphur } \\
\text { removal }\end{array}$ & $\begin{array}{l}\text { Ash } \\
\text { removal }\end{array}$ \\
\cline { 3 - 6 } & & \multicolumn{5}{c}{$(\%)$} \\
1 & 1 & 5.30 & 18.00 & 28.50 & 15.57 \\
2 & 2 & 5.00 & 17.50 & 32.165 & 17.86 \\
3 & 3 & 4.70 & 17.30 & 36.65 & 18.85 \\
4 & 4 & 4.60 & 17.00 & 38.00 & 20.16 \\
5 & 5 & 4.40 & 16.50 & 40.70 & 22.60 \\
6 & 6 & 4.00 & 16.00 & 46.09 & 24.95 \\
7 & 7 & 3.50 & 13.00 & 52.83 & 39.02 \\
8 & 8 & 3.70 & 14.50 & 50.13 & 31.90 \\
9 & 9 & 4.30 & 16.00 & 42.05 & 24.95 \\
10 & 11 & 5.00 & 17.00 & 32.61 & 20.26 \\
11 & 12 & 5.30 & 17.50 & 28.57 & 17.91 \\
12 & 13 & 5.00 & 18.00 & 32.61 & 15.57 \\
\hline \hline
\end{tabular}

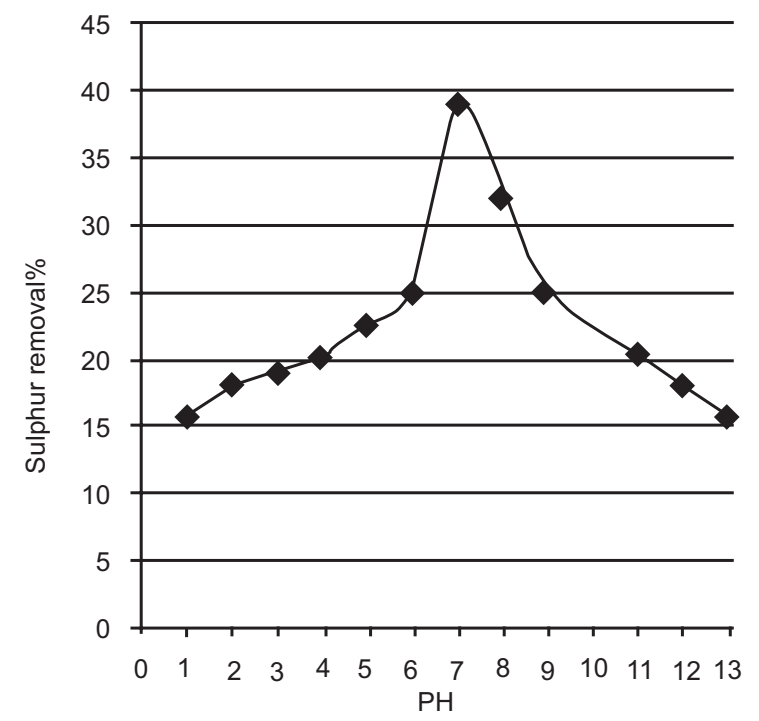

Fig. 1. Effect of $\mathrm{pH}$ on sulphur removal. 


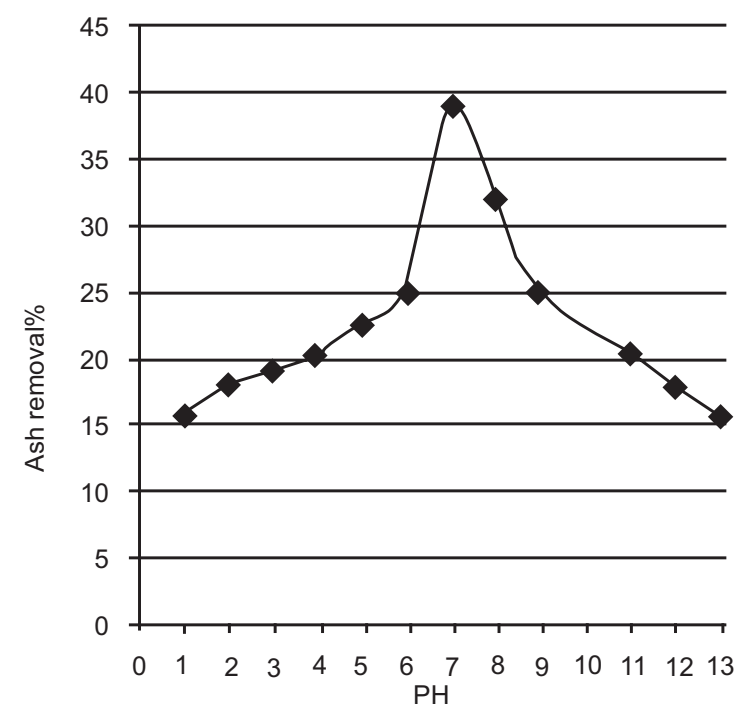

Fig. 2. Effect of $\mathrm{pH}$ on ash removal.

pyrite sulphur is alive in acidic media. As $\mathrm{pH}$ of solution increases towards a value of 7 , the improved and better results are met due to the hydrophobic characteristic of coal particles. The surface properties of coal samples are completely changed at this value. The hydrophobicity decreases and hydropholicity increases from $\mathrm{pH} 7$ to 13. This phenomenon demonstrates that the optimum value of $\mathrm{pH}$ is 7 where the sulphur and ash removal reach the highest value results and hydrophobicity becomes maximum (Abdullahya and Moghaddam, 2006).

Effect of separation time. In the second stage, effect of separation time on the separation efficiency is studied while keeping the $\mathrm{pH}$ and air velocity constant. The experimental tests are performed for pine oil as frothing agent under the above mentioned operating conditions. During the experimental test runs, the values of $\mathrm{pH}=7$ and air velocity $=13 \mathrm{scf} / \mathrm{h}$ were constant parameters. The experimental tests data is mentioned in Table 4 and effects of separation time on the sulphur and ash removals are shown in Fig. 3-4.

The results data indicated in Table 4 described that with the increase in separation time sulphur and ash removal was increased as shown in Fig. 3-4. It is observed that with the increase in time, separation efficiency also increases. After every $3 \mathrm{~min}$, the experimental tests are carried out and observed that there is increase in the separation efficiency of coal mixture. The results depict that by increasing separation time, the sulphur recovery also increases. The sulphur removal is optimum at the
Table 4. Effect of separation time on sulphur and ash removal

\begin{tabular}{lllll}
\hline \hline $\begin{array}{l}\text { Test } \\
\text { no. }\end{array}$ & $\begin{array}{l}\text { Time } \\
(\mathrm{min})\end{array}$ & $\begin{array}{l}\text { Ash } \\
\text { wt. }\end{array}$ & $\begin{array}{l}\text { Sulphur } \\
\text { removal }\end{array}$ & $\begin{array}{l}\text { Ash } \\
\text { removal }\end{array}$ \\
\cline { 3 - 5 } & & & (\%) & \\
\hline 1 & 40 & 13.00 & 52.80 & 39.02 \\
2 & 43 & 12.00 & 54.00 & 43.71 \\
3 & 46 & 11.70 & 55.00 & 45.12 \\
4 & 49 & 11.50 & 55.50 & 46.06 \\
5 & 52 & 11.00 & 56.30 & 48.40 \\
6 & 55 & 10.70 & 57.00 & 50.75 \\
\hline \hline
\end{tabular}

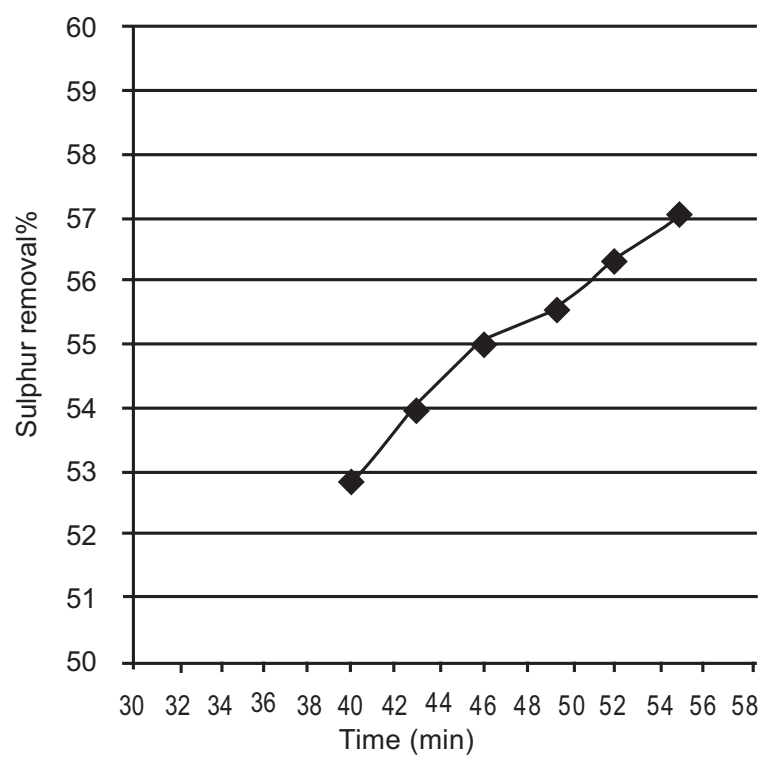

Fig. 3. Effect of separation time on sulphur removal.

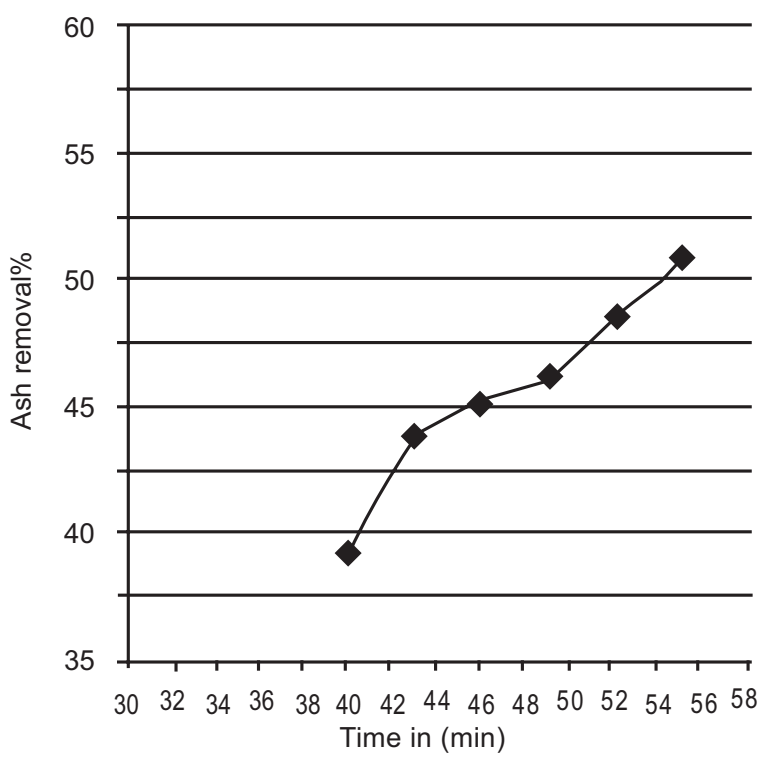

Fig. 4. Effect of separation time on ash removal. 
separation time $=55$ min (Abdullahya and Moghaddam, 2006).

Effect of air velocity. In third stage, effect of air velocity on the separation efficiency of the pyrite sulphur was studied by keeping the $\mathrm{pH}$, separation time and frothing agent rate constant. The values of $\mathrm{pH}=7$ and separation time $=40$ min was constant during the runs. The experimental tests data is mentioned in Table 5. The effects of air velocity on the sulphur and ash removals are shown in Fig. 5-6.

In Table 5, there is experimental runs data which describes that at low air velocity separation results showed that air bubbles were at the moderate level to escape the sulphur particles from column. The frothing agent almost gave the same trends. Sulphur recovery was improved with increase in air velocity.

Optimum results in terms of sulphur recovery had achieved by keeping air flow rate value at $90 \mathrm{scf} / \mathrm{h}$ from

Table 5. Effect of air velocity on sulphur and ash removal.

\begin{tabular}{llllc}
\hline \hline $\begin{array}{l}\text { Test } \\
\text { no. }\end{array}$ & $\begin{array}{l}\text { Ashwt. } \\
(\%)\end{array}$ & $\begin{array}{l}\text { Air } \\
\text { velocity } \\
(\mathrm{scf} / \mathrm{h})\end{array}$ & $\begin{array}{l}\text { Sulphur } \\
\text { removal }\end{array}$ & $\begin{array}{l}\text { Ash } \\
\text { removal }\end{array}$ \\
\hline 1 & 13.00 & 13.00 & 52.80 & 39.02 \\
2 & 12.75 & 20.00 & 54.00 & 40.19 \\
3 & 12.00 & 50.00 & 54.50 & 43.71 \\
4 & 11.65 & 60.00 & 55.00 & 45.35 \\
5 & 11.30 & 80.00 & 56.00 & 46.99 \\
6 & 11.10 & 90.00 & 56.00 & 47.90 \\
\hline \hline
\end{tabular}

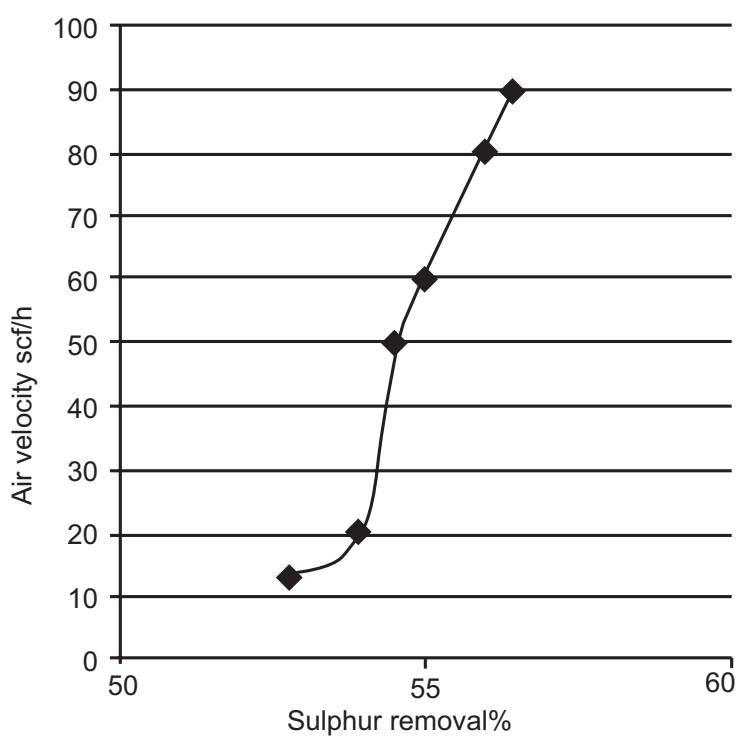

Fig. 5. Effect of air velocity on sulphur removal.

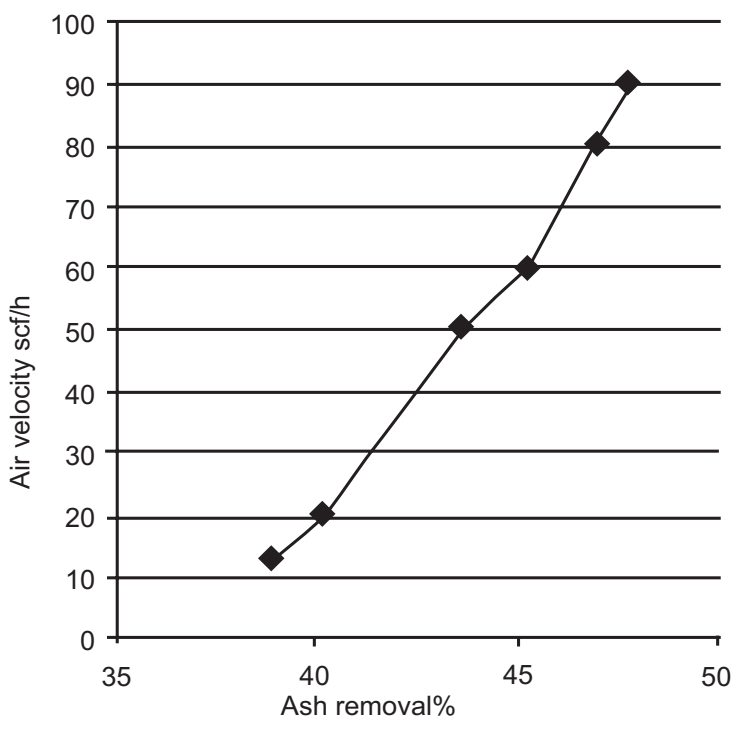

Fig. 6. Effect of air velocity on ash removal.

sixth experimental run in Table 5. However, at high air flow rate, the high velocity accounts for turbulence in the column. Due to high turbulence in the 'Froth Flotation' column, the less pyrite sulphur was captured in froth concentrate which results in decrease recovery. Similarly, the ash removal has also increased with the increase in air flow rate and became optimum at $90 \mathrm{scf} / \mathrm{h}$ (Abdullahya and Moghaddam, 2006).

\section{Conclusion}

The 'Froth Flotation' tests were performed for the removal of impurities from coal. Experimental results demonstrate that $\mathrm{pH}$, air flow rate and the separation time are the paramount factors for the removal of impurities. Frothing agent helps for stabilizing air bubble in the froth flotation column and capturing the refined coal through the column.

The pine oil is used as frothing agent or emulsifier. Pine oil was the main focus of many scientists by governing extraordinary results. Pine oil is used in controlling the size and stability of air bubbles from which refined coal can be skimmed through the flotation column. Present research shows that pine oil has its paramount role as good frothing agent for the sulphur/coal mixture. As the market price of pine oil is about $1 \$ / \mathrm{kg}$ which assists in making it most feasible reagent for its function as frothing agent.

Optimum conditions found for separation of pyrite sulphur from coal mixture after experiments are as follows: 
Maximum impurities removal has been achieved in neutral media (for $\mathrm{pH}=7$ ) which shows that neutral media helps increasing the hydrophobicity of selective (pyrite sulphur) component from coal mixture. Optimum value was $\mathrm{pH}=7$ and no significant separation efficiency was found greater than this value.

Separation time is the time used to pass air from the column and collect the de-sulphurized coal from the top. Minimum separation time used in experiment was $40 \mathrm{~min}$. By increasing the separation time, almost high separation efficiency of pyrite sulphur content were achieved.

Air velocity is found to be the principal parameter in removal of impurities from coal mixture. At low air velocity, air bubbles were not capable of capturing coal particles. Therefore, significant contents of impurities were achieved at moderate air flow rate. Turbulence in the 'Froth Flotation' column starts at the high flow rate which results in increased material recovery at the top thereby decreasing the purity of the coal sample, 90 $\mathrm{scf} / \mathrm{h}$ was found to be optimum value of air flow rate for removal of impurities from coal mixture in the flotation column.

\section{Acknowledgement}

The authors gratefully acknowledge the staff of Institute of Chemical Engineering and Technology, University of the Punjab, Lahore, Pakistan for their valuable advice and support.

Saadat Ullah Khan Suri would like to reveal his heartfelt gratitude to Engr. Asad Ullah Khan Suri for his brace and comprehending for conducting this research work.

Conflict of Interest. The authors declare no conflict of interest

\section{References}

Abdollahya, M., Moghaddam, A.Z. 2006. Desulfurization of mazino coal using combination of 'flotation' and 'leaching' with potassium hydroxide/methanol, Fuel, 85: 1117-11124.

ALA, 2011. Annual Report, 2011. American Lung Association 14 Wall Street Suite 8C, New York, USA. Retrieved from http://www.lung.org/assets/ documents/healthy- air/toxic-air-report.pdf on 0903-2012.

Attia,Y.A., Elezke, M., Ismail, M. 1993. Enhanced seperation of pyrite from oxidized coal by froth flotation using biosurface modification. International Journal of Mineral Processing, 37: 61-71.

Attia, Y. A. 1990. Feasibility of selective biomodification of pyrite floatability in coal desulfurization by froth flotation. Resources and Recycling, 3: 169-175.

Boylu, F., Laskowski, J.S. 2007. Rate of water transfer to flotation froth in the flotation of low-rank coal that also requires the use of oily collectors. International Journal of Mineral Processing, 83: 125-131.

Callow, J.M. 1916. Notes on Flotation. In: The Transaction of the American Institute of Mining Engineers, pp. 53-54, New York, USA.

Ceylan, K., Zeki, M. 2004. Effectiveness of the dense medium and the froth flotation methods in cleaning some Turkish lignite. Energy Conversion and Management, 45: 1407-1418 .

James, G. S., 2005a. Handbook of Coal Analysis, ASTM D-3175, vol. 166, pp. 56-57. A John Wiley \& Sons Inc. Publication, New Jersey, USA.

James, G. S. 2005b. Handbook of Coal Analysis, ASTM D-3174, vol. 166, pp. 51-53. A John Wiley \& Sons Inc., Hoboken, New Jersey, USA.

James, G. S. 2005c. Handbook of Coal Analysis, American Society for Testing and Materials. ASTM D-3177, vol. 166, pp.75-76. A John Wiley \& Sons Inc., Hoboken, New Jersey,USA.

James, G. S., 2005d. Handbook of Coal Analysis, ASTM D-2492, vol. 166, pp. 77. John Wiley \& Sons Inc., Hoboken, New Jersey, USA.

Jameson, G. J. 1992. Flotation cell development. In: The Aus IMM Annual Conference, pp. 25-31, Broken Hill, New South Wales, Australia.

Manlapig, E.V., Green, C., Parkinson, J. W., Murphy, A.S. 2001. The technology and economic incentives for recovering coal from tailings impoundments. In: SME Annual Meeting, Colorado Society for Mining, Metallurgy, and Exploration. Denver, Colorado, USA.

Maoming, F., Daniel, T. 2010. Nanobubble generation and its applications in froth flotation (part IV): Mechanical cells and specially designed column flotation of coal. Journal Mining Science and Technology, 20: 0641-0671.

Mitchell, D.R., Leonard, J.W. 1991. Coal Preparation, pp. $1-94,5^{\text {th }}$ edition, Society of Mining, Metallurgy and Exploration inc., Baltimore, Maryland, USA.

MMSCL, 2010. Anпual Report, 2010. Malegwin Mineral Services Company (pvt) Limited. 1A Gower Street, 
Cathays, Cardiff, CF244PAWales-United Kingdom. Retrieved on 13-01-2010 from http:// www. maelgwyn.com/who-we-are/wales-the-birthplaceof-flotation.

Osborne, D.G.D. 2012. Australian Dictionary of Biography, Canberra; Australian National Univeristy. Retrieved from http://adb.anu.edu.au/ biography/delprat-guillaume-daniel-5947.

Tastan, B. E. 2017. Clean up fly ash from coal burning plants by new isolated fungi Fusarium oxysporum and Penicillium glabrum. Journal of Environmental
Management, 200: 46-52.

UCS, 2012. Annual Report, 2012. Union of concerned Scientists 1825 St. NW, Ste , 800 Washignton DC 20006-1232, USA. Retrieved from https:/www. ucsusa.org/clean-energy/coal-and-other-fossilfuels/coal-air-pollution on 09-03-2012.

Xu, T.J., Ramanathan, T., Ting, Y.P. 2014. Bioleaching of incineration fly ash by Aspergillus niger precipitation of metallic salt crystals and morphological alteration of the fungus. Biotechnology Reports, 3: 8-14. 